\title{
Enzyme activities and pectin breakdown of sapodilla submitted to 1-methylcyclopropene
}

\author{
Patrícia Lígia Dantas de Morais( ${ }^{(1)}$, Luiz Carlos de Oliveira Lima(2), Maria Raquel Alcântara de Miranda ${ }^{(3)}$, \\ José Donizete Alves ${ }^{(3)}$, Ricardo Elesbão Alves ${ }^{(4)}$ and José Daniel Silva ${ }^{(3)}$
}

\begin{abstract}
(1)Universidade Federal Rural do Semi-Árido, Caixa Postal 137, CEP 59625-900 Mossoró, RN, Brazil. E-mail: plmorais@hotmail.com (2)Universidade Federal de Lavras, Caixa Postal 3037, CEP 37200-000 Lavras, MG, Brazil. E-mail: Icolima@ufla.br, jdalves@ufla.br (3)Universidade Federal do Ceará, Caixa Postal 6039, CEP 60455-900 Fortaleza, CE, Brazil. E-mail: rmiranda@ufc.br (4)Embrapa Agroindústria Tropical, Caixa Postal 3761, CEP 60511-110 Fortaleza, CE, Brazil. E-mail: elesbao@cnpat.embrapa.br
\end{abstract}

\begin{abstract}
The objective of this work was to investigate the influence of 1-methylcyclopropene (1-MCP) at $300 \mathrm{~nL} \mathrm{~L}^{-1}$ on activities of cell wall hidrolytic enzymes and pectin breakdown changes which Sapodilla (Manilkara zapota cv. Itapirema 31) cell wall undergoes during ripening. Sapodilla were treated with ethylene antagonist $1-\mathrm{MCP}$ at $300 \mathrm{~nL} \mathrm{~L}^{-1}$ for 12 hours and then, stored under a modified atmosphere at $25^{\circ} \mathrm{C}$ for 23 days. Firmness, total and soluble pectin and cell wall enzymes were monitored during storage. 1-MCP at $300 \mathrm{~nL} \mathrm{~L}^{-1}$ for 12 hours delayed significantly softening of sapodilla for 11 days at $25^{\circ} \mathrm{C}$. 1 -MCP postharvest treatment affected the activities of cell wall degrading enzymes pectinmethylesterase and polygalacturonase and completely suppressed increases in beta-galactosidase for 8 days, resulting in less pectin solubilization. Beta-galactosidase seems relevant to softening of sapodilla and is probably responsible for modification of both pectin and xyloglucancellulose microfibril network.
\end{abstract}

Index terms: Manilkara zapota, beta-galactosidase, ripening.

\section{Atividade de enzimas e degradação de pectinas de sapoti submetido ao 1-metilciclopropeno}

\begin{abstract}
Resumo - O objetivo deste trabalho foi investigar a influência do 1-metilciclopropeno (1-MCP) nas atividades das enzimas hidrolíticas da parede celular e nas mudanças na degradação da pectina durante o amadurecimento de sapoti (Manilkara zapota cv. Itapirema 31). Frutos de sapotizeiro foram tratados com o inibidor da ação do etileno, 1-MCP, na concentração de $300 \mathrm{~nL} \mathrm{~L}^{-1}$, por 12 horas e armazenados sob atmosfera modificada, à temperatura de $25 \pm 2^{\circ} \mathrm{C}$, por 23 dias. A firmeza, conteúdo de pectina total e solúvel e enzimas da parede celular foram avaliados durante todo o período de armazenamento. O 1-MCP a $300 \mathrm{~nL} \mathrm{~L}^{-1}$ por 12 horas retardou significativamente o amolecimento de sapoti por 11 dias a $25^{\circ} \mathrm{C}$. O tratamento com 1-MCP afetou a atividade das enzimas pectinametilesterase e poligalacturonase e inibiu o aumento da atividade beta-galactosidase por 8 dias, e, conseqüentemente, resultou em menor solubilização das substâncias pécticas. A beta-galactosidase parece ser relevante no amolecimento de sapoti e responsável pela modificação das pectinas e das xiloglucanas ligadas as microfibrilas de celulose.
\end{abstract}

Termos para indexação: Manilkara zapota, beta-galactosidase, amadurecimento.

\section{Introduction}

There is a great concern among growers and wholesalers on how to maintain the quality and nutritional attributes of tropical fruits in spite of the natural and rapid process of senescence. Ripening is the irreversible first step of senescence and the most characteristic alteration fruits undergo during ripening is softening or loss of firmness of skin and flesh, a consequence of cell wall and middle lamellae degradation by several hydrolytic enzymes.

Ethylene is the hormone responsible for triggering and coordinating ripening events in climacteric fruits. Studies on gene expression demonstrated that ripening is a programmed event that involves the controlled expression of specific genes, of which some are ethylene-dependent (Giovannoni, 2001). Thus, if technologies are to be developed to maintain quality and enhance postharvest 
conservation of commodities, it needs to be based on previous knowledge of the physiological processes that control ripening and senescence.

The use of ethylene antagonists has been an important tool in clarifying the physiological role of ethylene in the process of fruit ripening and also as a postharvest treatment to broaden the conservation potential of fruits. 1-Methylcyclopropene (1-MCP) is the best known and studied amongst ethylene inhibitors and has been shown to influence various physiological responses during fruit ripening, as ethylene production, respiratory rate, weight loss and cell wall degradation (Blankeship \& Dole, 2003). $1-\mathrm{MCP}$ postharvest treatment reduced the activity of cell wall enzymes and delayed ripening of avocados for four days (Jeong et al., 2002). Pears and plums treated with 1-MCP showed a reduction in ethylene production and respiratory rate (Dong et al., 2001; Mathooko et al., 2001).

Sapodilla (Manilkara zapota) is a climacteric fruit that ripens shortly after harvest, within 8 to 10 days at $26^{\circ} \mathrm{C}$ and 55\% RH (Morais et al., 2006). The studies on sapodilla were mainly restricted to storage life extension using low temperatures and modified atmosphere (Miranda et al., 2001), until Morais et al. (2006) tested different concentrations (100, 200 and $400 \mathrm{~nL} \mathrm{~L}^{-1}$ ) of 1-MCP on sapodilla. Postharvest treatment with 1-MCP at 200 and $400 \mathrm{~nL} \mathrm{~L}^{-1}$ delayed firmness loss and changes in pulp color, in sapodilla.

This work investigated the influence of $1-\mathrm{MCP}$ at $300 \mathrm{~nL} \mathrm{~L}^{-1}$ on activities of cell wall hidrolytic enzymes and cell wall pectin breakdown during ripening of sapodilla.

\section{Materials and Methods}

Sapodilla (Manilkara zapota) cultivar Itapirema-31 was harvested fully grown at physiological maturity from a commercial grower in Paraipaba, Ceará State, Brazil, and transported to Postharvest Physiology and Technology Laboratory in Fortaleza within 10 hours from harvest. Fruit were selected for uniformity of size and developmental stage, and then soaked in $1,000 \mathrm{mg} \mathrm{L}^{-1}$ Benomil fungicide for five minutes, rinsed and dried. Fruit were sorted into two groups, one was treated with $300 \mathrm{~nL} \mathrm{~L}^{-1} 1$-MCP for 12 hours and the other was control $\left(0 \mathrm{~nL} \mathrm{~L}^{-1} 1-\mathrm{MCP}\right)$.

Fruit were exposed to $300 \mathrm{~nL} \mathrm{~L}^{-1}$ of $1-\mathrm{MCP}$ in hermetically closed $186-\mathrm{L}$ mini-chambers at $25 \pm 2^{\circ} \mathrm{C}$ for 12 hours. The concentration used was achieved by releasing the gas from a commercial powdered formulation (Smartfresh from Rohm and Haas) with $0.14 \%$ of the active ingredient. Control fruit (not exposed to 1-MCP) were maintained under identical conditions. Immediately after chambers were opened, fruit were placed on polystyrene trays, four fruits per tray, and covered with $12 \mu \mathrm{m}$ PVC film and then stored at $25 \pm 2^{\circ} \mathrm{C}$ and $70 \pm 5 \% \mathrm{RH}$ for 23 days. Samples of fruit were evaluated on harvest day and after $4,8,11,14,17,20$, and 23 days for firmness, cell wall structural polysaccharides and for cell wall enzymes. After firmness was measured, fruit were peeled and mesocarpic tissue from each fruit were stored at $-70^{\circ} \mathrm{C}$ and used for analysis.

Fruit firmness was measured on a TA.XT2i Stable Micro Systems automatic texture analyzer with a $6 \mathrm{~mm}$ plunger. Measurements were performed at two equidistant points on the equatorial region of whole, unpeeled fruits and results expressed in Newton (N).

Pectinmethylesterase (PME, E.C. 3.1.1.11) was extracted and measured using modifications of the method of Jen \& Robinson (1984). Mesocarp tissue (5 g) was homogenized with $25 \mathrm{~mL}$ of ice-cold $0.2 \mathrm{~N} \mathrm{NaCl}$ in a Polytron. The homogenate was filtered through Whatman No. 1 paper and the residue collected as the enzyme crude extract. These former procedures were carried out at $4^{\circ} \mathrm{C}$. For PME activity assay, the reaction mixture contained $5 \mathrm{~mL}$ of enzyme crude extract and $30 \mathrm{~mL}$ of pectin solution $(1 \% \mathrm{v} / \mathrm{w}$ citrus pectin in $0.1 \mathrm{M}$ $\mathrm{NaCl}$ ) and the rate of pectin demethylation was monitored through titration with $\mathrm{NaOH} 0.025 \mathrm{M}$ at $\mathrm{pH} 7.0$ for $10 \mathrm{~min}$. One unit of pectinmethylesterase was defined as the amount of enzyme capable of demethylating pectin corresponding to the consumption of $1 \mathrm{nmol} \mathrm{NaOH} \mathrm{min}{ }^{-1} \mathrm{~g}^{-1}$ and results were expressed as one unit of activity per minute per gram fresh matter.

Polygalacturonase (PG, E.C. 3.2.1.15) was extracted as described by Buescher \& Furmanski (1978) and its activity was determined according to Pressey \& Avants (1973). Mesocarp tissue (5 g) was homogenized with $50 \mathrm{~mL}$ of ice-cold water. The homogenate was filtered through Whatman No. 1 paper; the residue was washed in $20 \mathrm{~mL}$ of ice-cold water and then resuspended in $20 \mathrm{~mL}$ of $1.0 \mathrm{~N} \mathrm{NaCl}$ and stirred for $1 \mathrm{~min}$. It was then adjusted to $\mathrm{pH} 6.0$ let to rest for 1 hour. The volume was completed to $30 \mathrm{~mL}$ with $1.0 \mathrm{~N} \mathrm{NaCl}$ and filtered through Whatman No. 1 paper and the residue collected as the enzyme crude extract. All previous steps were conducted at $4^{\circ} \mathrm{C}$. For PG activity assay, the reaction 
mixture consisted of $200 \mu \mathrm{L}$ enzyme crude extract plus $50 \mu \mathrm{L} 0.25 \%$ polygalacturonic acid in $37.5 \mathrm{mM}$ sodium acetate buffer, $\mathrm{pH}$ 5.0. The reaction mixture was incubated for three hours at $30^{\circ} \mathrm{C}$ followed by a boiling water bath to stop the reaction. The reducing groups liberated were determined according to Somogyi technique modified by Nelson (1944). Results were expressed as units of $\mathrm{PG}$ activity per minute per gram fresh matter.

Beta-galactosidase ( $\beta$-GAL, E.C. 3.2.1.23) was extracted as described by Kitagawa et al. (1995) and its activity determined as Dey \& Pridham (1969). Mesocarp tissue $(10 \mathrm{~g})$ was homogenized with $20 \mathrm{~mL}$ of $0.1 \mathrm{M}$ acetate phosphate buffer, $\mathrm{pH} 5.0$, with $1 \%$ polyvinylpyrrolidone (PVP) and centrifuged $(10,000 \mathrm{~g}, 15 \mathrm{~min})$. The pellet was resuspended in $0.1 \mathrm{M}$ acetate phosphate buffer, $\mathrm{pH}$ 5.0, plus $0.005 \mathrm{M}$ 2-mercaptoethanol and then centrifuged $(10,000 \mathrm{~g}, 15 \mathrm{~min})$. The pellet was resuspended in $0.02 \mathrm{M}$ sodium acetate buffer, $\mathrm{pH} 5.0$, plus $3 \mathrm{M} \mathrm{NaCl}$ and stirred for 12 hours. The suspension was centrifuged $(14,000 \mathrm{~g}, 20 \mathrm{~min})$ and the supernatant dialyzed for 24 hours against water. All previous steps were conducted at $4^{\circ} \mathrm{C}$. The beta-galactosidasic activity was assayed for hydrolysis of p-nitrophenil- $\beta$-galactopyranoside and the reaction mixture consisted of crude enzyme extract and $0.003 \mathrm{M}$ substrate in McIlwaine buffer, $\mathrm{pH}$ 4.0. After $15 \mathrm{~min}$ at $37^{\circ} \mathrm{C}$, the reaction was terminated by $0.1 \mathrm{M}$ sodium carbonate and the p-nitrophenol released was measured spectrometrically at $400 \mathrm{~nm}$. Results were expressed as units of beta-galactosidase activity per minute per gram fresh matter.

The experiment was conducted in a $2 \times 8$ factorial design with a treatment defined as the 1-MCP dosage (300 $\mathrm{nL} \mathrm{L}^{-1}$ ) plus control and eight times of evaluation $(0,4,8,11,14,17,20$, and 23 days). The experimental parcels were made up of 12 fruits, being three repetitions with four fruits each. Data were analyzed as averages of 12 determinations \pm standard deviation and by ANOVA, using SISVAR.

\section{Results and Discussion}

Sapodilla treated at postharvest with $1-\mathrm{MCP}$ at $300 \mathrm{~nL} \mathrm{~L}^{-1}$ softened much slower than control fruit (Figure 1). After 8 days of storage at $25^{\circ} \mathrm{C}$ and $70 \%$ $\mathrm{RH}$, firmness of control fruit decreased from $79.74 \mathrm{~N}$ at harvest day to $7.79 \mathrm{~N}$. Meanwhile, softening of 1-MCP treated fruit was significantly delayed, reaching $15.37 \mathrm{~N}$ after 11 days of storage. After storage for
23 days, no significant differences in firmness were found between 1-MCP treated and controls. The sharp decrease in firmness of control fruit observed up to day 8 could be correlated to the climacteric ethylene synthesis (Miranda et al., 2002) and after that, firmness of control fruit decreased slowly and continuously.

These results support the observation of Araújo-Neto et al. (2001) that sapodilla 'Itapirema-31', stored for 8 days at $24^{\circ} \mathrm{C}$ with no postharvest treatment, exhibited a firmness loss from $78.6 \mathrm{~N}$ to $5.49 \mathrm{~N}$. It was also observed that 1-MCP kept firmer for a longer period: peaches, plums and apricot (Lurie \& Weksler, 2005) and 'Simmonds' avocado (Jeong et al., 2002). The delay in softening observed in 1-MCP treated sapodilla indicates the importance of ethylene to ripening of climacteric fruits and the ability of the 1-MCP treated fruit to soften at the end of storage suggests that new ethylene cell membrane receptors were synthesized and cells regained their sensibility to this hormone, as sapodilla ripened regularly.

The reduction in firmness observed as fruits ripen is mostly a consequence of modifications on cell wall carbohydrate metabolism and on its structure (Ali et al., 2004). Fruit firmness is considered one of the main quality attributes and often limits postharvest shelf life. In the case of sapodilla, whenever the fruit is apt for consumption, it is so soft that it is very susceptible to mechanical damage and pathogen attack.

In sapodilla cell wall, the soluble pectin content increased through storage with significant differences between treatments (Figure 2). The total pectin content

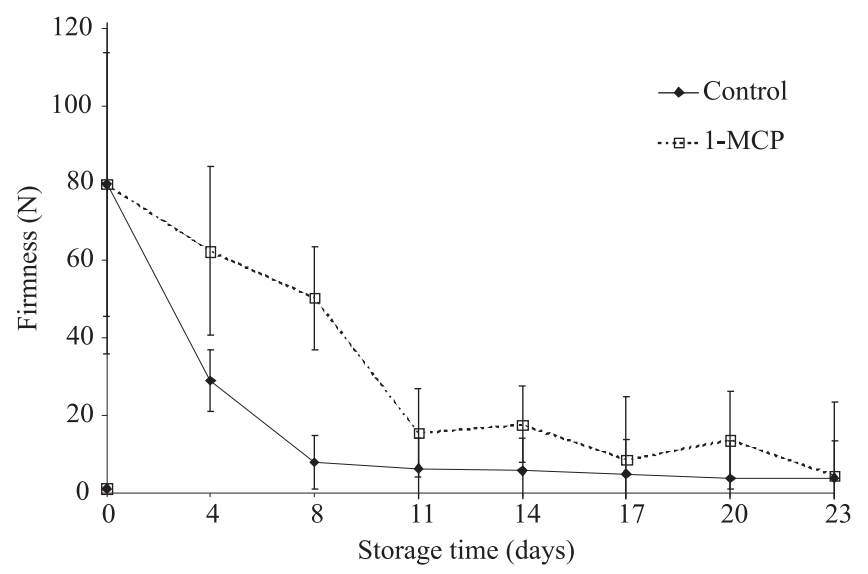

Figure 1. Changes in firmness during postharvest storage of sapodilla treated with $300 \mathrm{~nL} \mathrm{~L}^{-1} 1$-methylcyclopropene (1-MCP) ( $\square$ ) for 12 hours and control $(\bullet)$, at $25 \pm 2^{\circ} \mathrm{C}$ and $70 \pm 5 \% \mathrm{RH}$. 
of sapodilla cell wall also exhibited significant differences between 1-MCP-treated and control fruit (Figure 3). At harvest day, the total pectin level was $630.52 \mathrm{mg} 100 \mathrm{~g} \mathrm{~g}^{-1}$ and for control fruit, the increase in soluble forms is consistent with the decline in total pectin levels during sapodilla ripening and could be explained by a faster metabolic rate resulting in greater solubilization of pectin.

1-MCP-treated sapodilla showed a smaller increase in soluble pectin levels and maintained high total pectin contents through storage, corroborating to the idea that 1-MCP maintains firmness due to inhibition of cell wall degradation. Pectin was synthesized at the beginning of storage of 1-MCP-treated fruits and started to decline

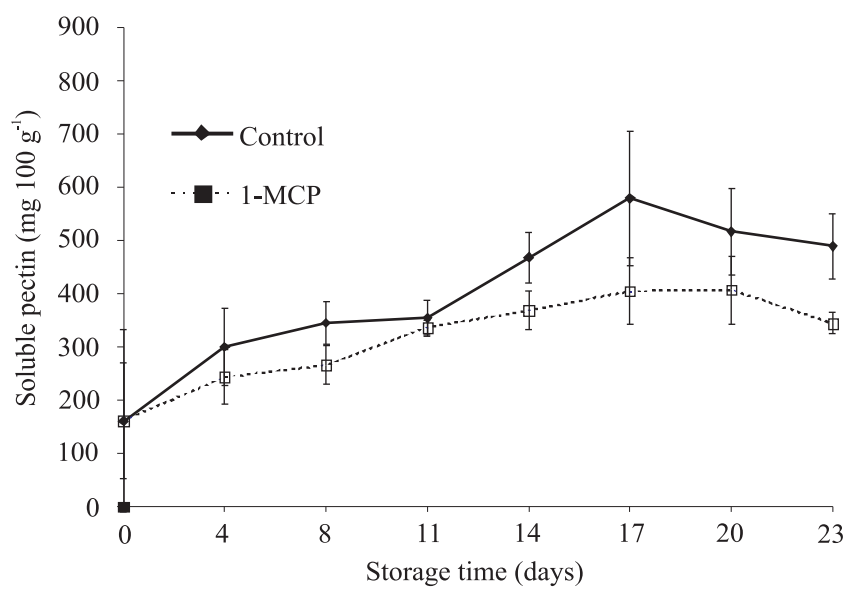

Figure 2. Changes in soluble pectin content during postharvest storage of sapodilla treated with $300 \mathrm{~nL} \mathrm{~L}^{-1}$ 1-methylcyclopropene (1-MCP) ( $\square$ ) for 12 hours and control $(\diamond)$, at $25 \pm 2{ }^{\circ} \mathrm{C}$ and $70 \pm 5 \% \mathrm{RH}$.

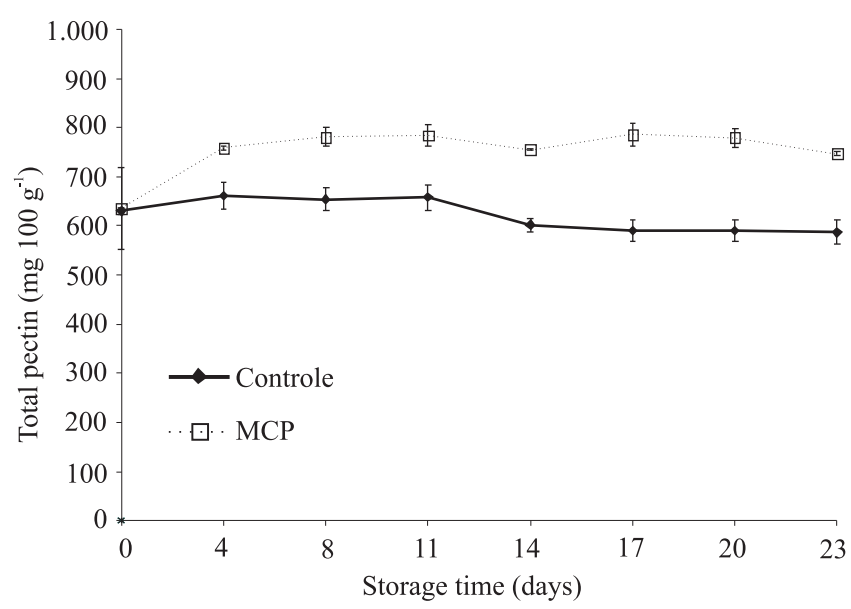

Figure 3. Changes in total pectin content of 'Itapirema 31' sapodilla treated with $300 \mathrm{~nL} \mathrm{~L}^{-1} 1$-methylcyclopropene (1-MCP) ( $\square$ ) for 12 hours and control $(\diamond)$ stored under modified atmosphere at $25 \pm 2{ }^{\circ} \mathrm{C}$ and $70 \pm 5 \% \mathrm{RH}$. after 21 days. Vilas Boas et al. (2000) reported synthesis of pectin during storage of tomatoes and Pinheiro et al. (2007) also verified similar 1-MCP effects on soluble and total pectin contents as bananas ripened. This increase in soluble forms of pectic substances is concomitant to firmness loss, observed during fruit ripening.

Regarding their external appearance, control fruits started to show senescence symptoms after 15 days of storage, meanwhile those treated with 1-MCP showed the same symptoms only after 21 days of storage. Miranda et al. (2001) observed, in physiologically mature sapodilla, similar total and soluble pectin contents compared to those reported here and also a similar pattern of conversion of total to soluble forms as fruit ripened.

The softening process is thought to be a consequence of de-esterification of pectin catalyzed by PME followed by pectin depolymerization catalyzed by PG, thus PG activity is dependent on PME for making substrate available (Abu-Goukh \& Bashir, 2003). Cell wall PME activities were high in sapodilla (Figure 4). In control fruit, PME activity increased gradually until day 11 reaching ca. 480 activity units and then started to decrease. Previous works reported similar activity patterns for PME in sapodilla, guava, papaya and "carambola" (Miranda et al., 2001; Abu-Goukh \& Bashir, 2003; Ali et al., 2004).

When sapodilla was treated with 1-MCP, PME maximum activity was delayed to day 14 and reached

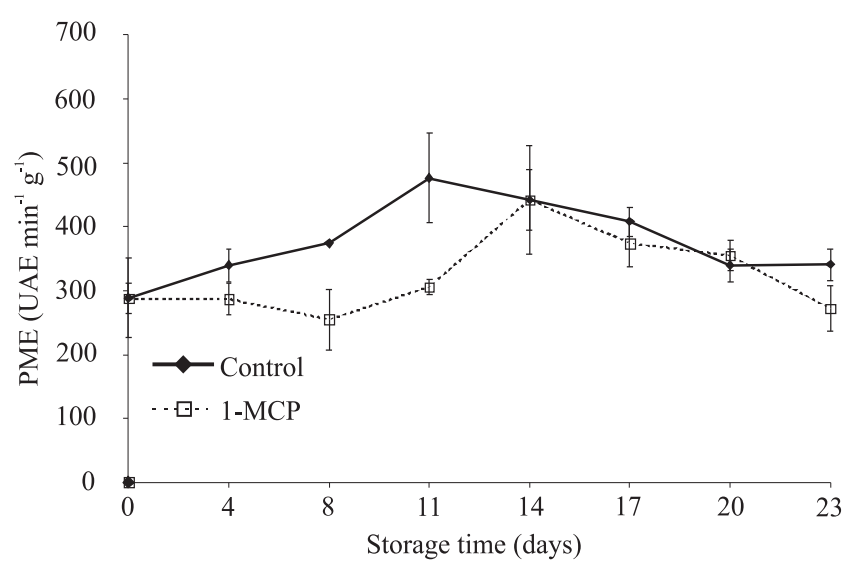

Figure 4. Changes in pectinmethylesterase (PME) activity during postharvest storage of sapodilla treated with $300 \mathrm{~nL} \mathrm{~L}^{-1} 1$-methylcyclopropene (1-MCP) ( $\square$ ) for 12 hours and control $(\diamond)$, at $25 \pm 2^{\circ} \mathrm{C}$ and $70 \pm 5 \% \mathrm{RH}$. 
lower levels (ca. 440 activity units), showing that although PME activity was not suppressed by 1-MCP, its induction was restricted. In sapodilla, the high pectin demethylesterification activity catalyzed by PME is probably required not only for subsequent PG activity, which was very low as observed in Figure 5, but also to modify $\mathrm{pH}$ and cation exchange properties of cell wall, which might impact other cell wall enzymes. In bananas, 1-MCP treatment did not delay PME peak activity; although the levels were markedly lower indicating that cell wall hydrolases are largely dependent on ethylene production and perception (Lohani et al., 2004).

PG activity increased during storage, reaching a maximum (ca. 9 activity units) on days 8 and 14 for control and 1-MCP treated sapodilla, respectively (Figure 5) and then decreased. The 1-MCP treatment delayed PG peak, although the activity levels were significantly low for both treatments. Low activity values presented for PG were similar to those observed by Miranda et al. (2001) for sapodilla stored under ambient and modified atmosphere.

During ripening of avocado and banana, PG activity was very low in pre-climacteric stage then, increased as climacteric proceeded and continued increasing during postclimacteric phase. In both cases, PG activity was preceded by PME (Jeong et al., 2002; Lohani et al., 2004). When avocado were treated with 1-MCP, PG activity was not recovered although firmness reached values similar to control (Jeong et al., 2002).

For quite some time, changes in firmness observed during ripening were mainly credited to pectin hydrolyses by PG. Now, there is evidence that other mechanisms are also involved with fruit softening (Redgwell \& Fischer, 2002). Giovannoni (2001) observed that PG is not the

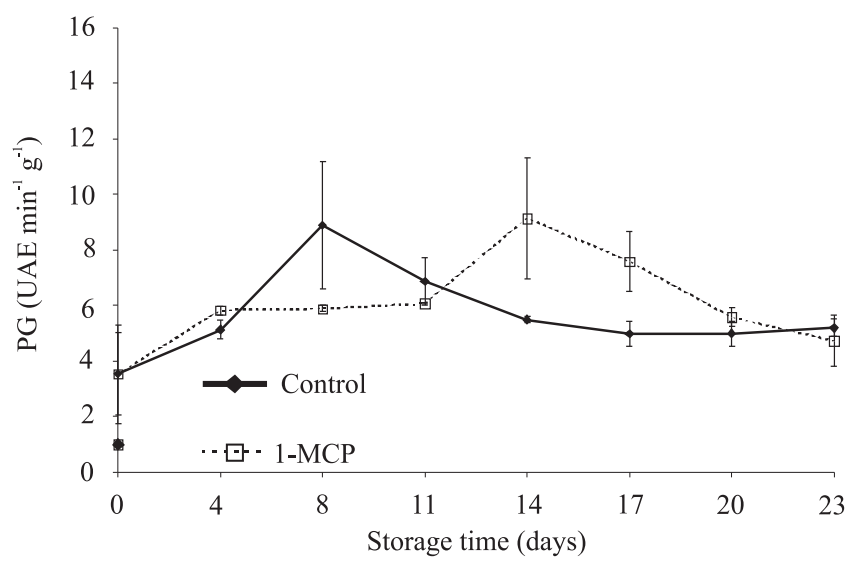

Figure 5. Changes in polygalacturonase (PG) activity during postharvest storage of sapodilla treated with $300 \mathrm{~nL} \mathrm{~L}^{-1} 1$-methylcyclopropene (1-MCP) ( $\square$ ) for 12 hours and control $(\diamond)$, at $25 \pm 2{ }^{\circ} \mathrm{C}$ and $70 \pm 5 \% \mathrm{RH}$. main responsible for tomato softening, since in transgenic tomatoes, the inhibition of PG activity had very little effect on firmness loss. In sapodilla, the low PG activity reported in this study and in previous work (Miranda et al., 2001) indicates also that it is not the main responsible for softening.

At harvest day, there was no detectable beta-galactosidase activity in sapodilla, but as ripening progressed there was a significant increase in activity in control fruit (Figure 6). In control fruits, betagalactosidase activity reached $352.5 \mathrm{UAE} \mathrm{min}^{-1} \mathrm{~g}^{-1}$ at day 4 , meanwhile the 1-MCP treated fruit reached 432.80 UAE $\mathrm{min}^{-1} \mathrm{~g}^{-1}$ only at day 14 . The delay in beta-galactosidase activity observed in 1-MCP treated sapodilla indicates the importance of ethylene to the activity of this cell wall hydrolase. Consistent with the marked initial suppression of beta-galactosidase levels in 1-MCP-treated sapodilla, softening was significantly delayed.

Studies on gene expression in tomatoes showed an increase in expression of beta-galactosidase gene during climacteric and when fruits were treated with exogenous ethylene (Moctezuma et al., 2003). These authors suggested the use ethylene antagonists or inhibitors, as 1-MCP, to slow the activity of beta-galactosidase and prolong the postharvest life of tomatoes. When beta-galactosidase was inhibited, there was a great reduction in tomato firmness loss (Alexander \& Grierson, 2002). Miranda et al. (2001) reported that betagalactosidase activity increased as sapodilla softened and observed through microscopic analysis the loosening of cell wall, to which beta-galactosidase is associated.

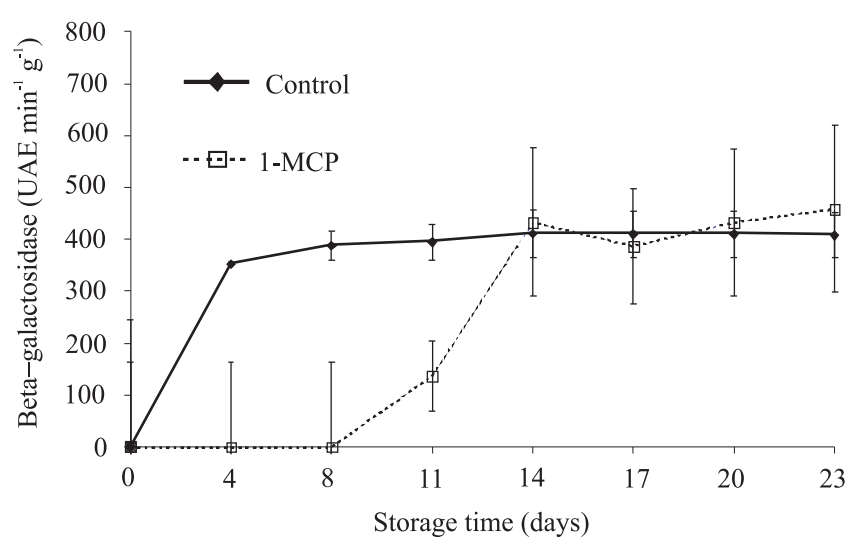

Figure 6. Changes in beta-galactosidase activity during postharvest storage of sapodilla treated with $300 \mathrm{~nL} \mathrm{~L}^{-1} 1$-methylcyclopropene (1-MCP) ( $\square$ ) for 12 hours and control $(\bullet)$, at $25 \pm 2^{\circ} \mathrm{C}$ and $70 \pm 5 \% \mathrm{RH}$. 


\section{Conclusions}

1. The effects of 1-methylcyclopropene on firmness loss result from restricted induction or inhibition of cell wall hydrolytic enzymes as pectinamethylesterase, polygalacturonase and beta-galactosidase leading to lower pectin solubilization.

2. The softening phenomenon of sapodilla should be mainly attributed to modification of pectin network brought about by beta-galactosidase.

\section{References}

ABU-GOUKH, A.B.A.; BASHIR, H.A. Changes in pectic enzymes and cellulase activity during guava fruit ripening. Food Chemistry, v.83, p.213-218, 2003.

ALEXANDER, L.; GRIERSON, D. Ethylene biosynthesis and action in tomato: a model for climacteric fruit ripening. Journal of Experimental Botany, v.53, p.2039-2055, 2002.

ALI, Z.M.; CHIN, L.H.; LAZAN, H. A comparative study on wall degrading enzymes, pectin modifications and softening during ripening of selected tropical fruits. Plant Science, v.167, p.317-327, 2004.

ARAUJO-NETO, S.E.; PRACA, E.F.; CARVALHO, E.F.; ALVES, R.E.; MENEZES, J.B.; MORAIS, E.A. Determinação do ponto de colheita e índices de maturação para sapoti (Manilkara achras). Revista Brasileira de Fruticultura, v.23, p.45-49, 2001.

BLANKENSHIP, S.M.; DOLE J.M. 1-Methylcyclopropene: a review. Postharvest Biology and Technology, v.28, p.1-25, 2003.

BUESCHER, R.W.; FURMANSKI, R.J. Role of pectinesterase and polygalacturonase in the formation of woolliness in peaches. Journal of Food Science, v.43, p.264-266, 1978.

DEY, P.M.; PRIDFHAM, J.B. Purification and properties of $\alpha$-galactosidases from Vicia faba seeds. Biochemistry Journal, v.113, p.49-55, 1969.

DONG, L.; ZHOU, H.W.; SONEGO, L.; LERS, A.; LURIE, S. Ripening of 'Red Rosa' plums: effect of ethylene and 1-methylcyclopropene. Australian Journal of Plant Physiology, v.28, p.1039-1045, 2001.

GIOVANNONI, J. Molecular biology of fruit maturation and ripening. Annual Review of Plant Physiology and Plant Molecular Biology, v.52, p.725-749, 2001.

JEN, J.J.; ROBINSON, M.L.P. Pectolytic enzymes in sweet bell peppers (Capsicum annuum L.). Journal of Food Science, v.49, p.1085-1087, 1984.

JEONG, J.; HUBER, D.J.; SARGENT, S. Influence of 1-methylcyclopropene (1-MCP) on ripening and cell-wall matrix polysaccharides of avocado (Persea americana) fruit. Postharvest Biology and Technology, v.25, p.241-256, 2002.
KITAGAWA, Y.; KANAYAMA,Y; YAMAKI, S. Isolation of $\beta$-galactosidase fractions from Japanese pear: activity against native cell wall polysaccharides. Physiologia Plantarum, v.93, p.545-550, 1995.

LOHANI, S.; TRIVEDI, P.K.; NATH, P. Changes in activities of cell wall hydrolases during ethylene-induced ripening in banana: effect of 1-MCP, ABA and IAA. Postharvest Biology and Technology, v.31, p.119-126, 2004.

LURIE, S.; WEKSLER, A. Effects of 1-methylcyclopropene on stone fruits. Acta Horticulturae, v.682, p.85-90, 2005.

MATHOOKO, F.M.; TSUNASHIMA, Y.; OWINO, W.Z.O.; KUBO, Y.; INABA, A. Regulation of genes encoding ethylene biosynthetic enzymes in peach (Prunus persica L.) fruit by carbon dioxide and 1-methylcyclopropene. Postharvest Biology and Technology, v.21, p.265-281, 2001.

MIRANDA, M.R.A.; SILVA, F.S.; ALVES, R.E.; FILGUEIRAS, H.A.C.; ARAUJO, N.C.C. Storage of two types of sapodilla under ambient condition. Revista Brasileira de Fruticultura, v.24, p.644-646, 2002.

MIRANDA, M.R.A.; SILVA, F.S.; FILGUEIRAS, H.A.C.; ALVES, R.E.; ARÁUJO, N.C.C. Enzymes and pectin breakdown of sapodilla during modified atmosphere storage. Proceedings of the Interamerican Society for Tropical Horticulture, v.45, p.18-21, 2002.

MOCTEZUMA, E.; SMITH, D.L.; GROSS, K.C. Effect of ethylene on mRNA abundance of three $\beta$-galactosidase genes in wild type and mutant tomato fruit. Postharvest Biology and Technology, v.28, p.207-217, 2003.

MORAIS, P.L.D.; LIMA, L.C.O.; ALVES, R.E.; FILGUEIRAS, H.A.C.; ALMEIDA, S.A. Alterações físicas, fisiológicas e químicas durante o armazenamento de duas cultivares de sapoti. Pesquisa Agropecuária Brasileira, v.41, p.549-554, 2006.

NELSON, N.A. A photometric adaptation of Somogyi method for the determination of glucose. The Journal of Biological Chemistry, v.153, p.375-380, 1944.

PINHEIRO, A.C.M.; VILAS BOAS, E.V.B.; ALVES, A.P. ; SELVA, M.L. Amadurecimento de bananas 'Maçã' submetidas ao 1-metilciclopropeno. Revista Brasileira de Fruticultura, v.29, p.1-4, 2007.

PRESSEY, R.; AVANTS, J.K. Separation and characterization of endopolygalacturonase and exopolygalacturonase from peaches. Plant Physiology, v.52, p.252-256, 1973.

REDGWELL, R.R.; FISCHER, M. Fruit texture, cell wall metabolism and consumer perceptions. In: KNEE, M. (Ed.). Fruit quality and its biological basis. Sheffield: Sheffield Academic Press, CRC Press LLC., 2002. p.46-88.

VILAS BOAS, E.V.B.; CHITARRA, A.B.; MALUF, W.R.; CHITARRA, M.I.F. Modificações texturais de tomates heterozigotos no loco alcobaça. Pesquisa Agropecuária Brasileira, v.35, p.1447-1453, 2000.

Received on July 20, 2007 and accepted on December 3, 2007 